๑Т. В. Фролова, Н. С. Осман, Н. Ф. Стенкова

Харківсъкий національний медичний університет

\title{
СТАН КІСТКОВОЇ ТКАНИНИ ТА ВІТАМІН D-СТАТУС У ДІТЕЙ В ПЕРІОД ДРУГОГО РОСТОВОГО СПУРТУ
}

\begin{abstract}
Мета дослідження - визначення структурно-срункціонального стану кісткової тканини та статусу вітаміну $\mathrm{D}_{3}$ у школярів у період другого ростового спурту.

Матеріали та методи. Обстежено 205 умовно здорових дітей віком 9-17 років, які були розподілені на групи залежно від наявності ростового спурту (РC) та його інтенсивності. I група - 50 дітей, які за поточний рік прибавили у рості 8-12 см; II група - 46 дітей, які за поточний рік прибавили у рості більше 12 см, III група - 109 дітей, які не мали РС. Обстеження включало аналіз даних анамнезу, оцінку рівня фрізичного та статевого розвитку, ультразвукову та рентгенівську денситометрію, визначення рівня 25-(OH)- $\mathrm{D}_{3}$.

Результати дослідження та їх обговорення. При проведенні ультразвукової денситометрії (УД) дітям зниження мінеральної щільності кісткової тканини (МЩКТ) діагностовано: I група - 24 дитини (48,0 \%), середній показник Z-sсоге

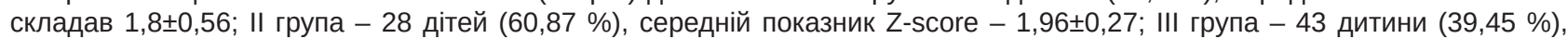
середній показник Z-score - 1,68 $\pm 0,72$.

За допомогою DXA було обстежено 32 дитини, у яких при проведенні УД виявлено зниження МщкT; у 18 з них (56,25 \%) було діагностовано зниження МЩКТ. Відсоток дітей зі зниженням МЩКТ у період ростового спурту (I група) та інтенсивного ростового спурту (II група) складав, відповідно, 38,9 та 50,0 \%. Середній рівень вітаміну 25-(OH)-D у дітей I групи зі зниженою МЩКТ становив $(39,04 \pm 11,84)$ нмоль/л; у дітей із нормальною МщКТ - $(42,43 \pm 6,3)$ нмоль/л; у дітей II групи зі зниженою МЩКТ його середній рівень становив $(45,68 \pm 5,48)$ нмоль/л, при нормальній МЩКТ - $(45,47 \pm 4,69)$ нмоль/л; у дітей III групи зі зниженою МщКТ його середній рівень склав $(36,73 \pm 8,94)$ нмоль/л, що вірогідно відрізняється від його значень у дітей 3 нормальною МЩКТ - $(42,91 \pm 9,1)$ нмольл $(p<0,05)$

Висновки. Зниження мінеральної щільності кісткової тканини у дітей шкільного віку в період ростового спурту відбувається на тлі недостатності або десріциту вітаміну $D_{3}$, проте найбільш суттєвим чинником зниження МщкТ є саме відставання процесів накопичення кісткової маси на тлі інтенсивного лінійного росту скелета.
\end{abstract}

Ключові слова: денситометрія; ростовий спурт; вітамін $\mathrm{D}_{3}$; остеопороз.

СОСТОЯНИЕ КОСТНОЙ ТКАНИ И ВИТАМИН D-СТАТУС У ДЕТЕЙ В ПЕРИОД ВТОРОГО РОСТОВОГО СПУРТА

Цель исследования - определение структурно-сункционального состояния костной ткани и витамин D-статуса у детей в период второго ростового спурта.

Материалы и методы. Обследовано 205 условно здоровых детей возрастом 9-17 лет. Дети были разделены на группы в зависимости от наличия ростового спурта (PC) и его интенсивности. I группа - 50 детей, которые за текущий год выросли на 8-12 см; II группа - 46 детей, которые за текущий год выросли более чем на 12 см, III группа - 109 детей, у которых не было РС. Обследование включало анализ данных анамнеза, оценку физического и полового развития, ультразвуковую и рентгеновскую денситометрию, определение 25-(OH)- $\mathrm{D}_{3}$.

Результаты исследования и их обсуждение. При проведении ультразвуковой денситометрии (УД) детям снижение минеральной плотности костной ткани (МПКТ) было диагностировано: I группа - 24 ребенка (48,0 \%), средний показатель

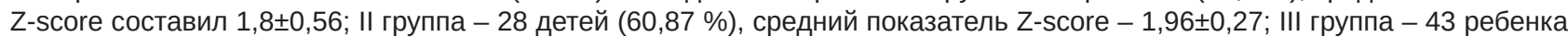

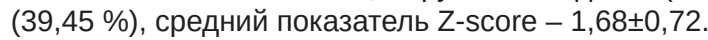

При помощи DXA было обследовано 32 ребенка, у которых при проведении Уд выявлено снижение МПКT; у 18 из них (56,25 \%) было диагностировано снижение МПКТ. Количество детей со снижением МПКТ в период ростового спурта (I группа) и интенсивного ростового спурта (II группа) составило, соответственно, 38,9 и 50,0%. Средний уровень витамина $25-(\mathrm{OH})-\mathrm{D}_{3}$ у детей I группы со снижением МПКТ составил $(39,04 \pm 11,84)$ нмоль/л; у детей с нормальной МПКТ - $(42,43 \pm$ $6,3)$ нмоль/л; у детей II группы со снижением МПКТ его средний уровень составил $(45,68 \pm 5,48)$ нмоль/л, с нормальной МПКТ - $(45,47 \pm 4,69)$ нмоль/л; у детей III группы со снижением МПКТ его средний уровень $(36,73 \pm 8,94)$ нмоль/л, что достоверно отличается от его значений у детей с нормальной МПКТ - $(42,91 \pm 9,1)$ нмоль/л $(p<0,05)$.

Выводы. Снижение минеральной плотности костной ткани у детей школьного возраста в период ростового спурта происходит на фоне недостаточности или дефицита витамина $\mathrm{D}_{3}$, но, в то же время, наибольшее значение в снижении МПКТ играет несоответствие скорости накопления костной ткани линейному росту скелета.

Ключевые слова: денситометрия; ростовой спурт; витамин $\mathrm{D}_{3}$; остеопороз.

CONDITION OF THE BONE TISSUE AND VITAMIN D STATUS IN CHILDREN DURING THE SECOND GROWTH SPURT

The aim of the study - to determine the structural and functional condition of the bone tissue and the vitamin D status in schoolchildren during the second growth spurt.

Materials and Methods. 205 nominally healthy children aged from 9 to 17 were examined after their categorization depending on the presence/absence of the growth spurt (GS) and its intensity. Group 1 consists of 50 children who have grown up by 8-12 cm for the current year; Group 2 is represented by 46 children who have grown up by over $12 \mathrm{~cm}$, Group 3 covers 109 children who have had no growth spurt. The examination included analysis of the medical history, evaluation of physical and sexual development, ultrasound and X-Ray densitometry, determination of the $25-(\mathrm{OH})-\mathrm{D}_{3}$ level. 
Results. The ultrasound densitometry (UD) revealed a reduced mineral density of the bone tissue (MDBT) in children as

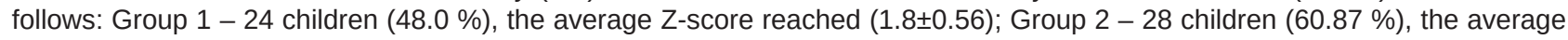
Z-score amounted to (1.96 \pm 0.27$)$; Group 3 - 43 children (39.45 \%), the average Z-score reached (1.68 \pm 0.72$)$. DXA allowed for examining 32 children with a reduced MDBT as shown by the ultrasound; 18 (56.25\%) of them were diagnosed with a reduced MDBT. Percentage of the children with a reduced MDBT during the growth spurt (Group 1) and the intensive growth spurt (Group 2) reached $38.9 \%$ and $50.0 \%$, respectively. The average $25-(\mathrm{OH})-\mathrm{D}_{3}$ level in children with a reduced MDBT belonging to Group 1 was $(39.04 \pm 11.84) \mathrm{nmol} / \mathrm{L}$; in children with a normal MDBT, it was $(42.43 \pm 6.3) \mathrm{nmol} / \mathrm{L}$; in children with a reduced MDBT belonging to Group 2, its average level reached $(45.68 \pm 5.48) \mathrm{nmol} / \mathrm{L}$, the average $25-(\mathrm{OH})-\mathrm{D}_{3}$ level in case of a normal MDBT was $(45.47 \pm 4.69)$ $\mathrm{nmol} / \mathrm{L}$; in children with a reduced MDBT falling under Group 3 the average value was $(36.73 \pm 8.94) \mathrm{nmol} / \mathrm{L}$ which is evidently different from the corresponding vitamin level in children with a normal MDBT, namely $(42.91 \pm 9.1) \mathrm{nmol} / \mathrm{L},(p<0.05)$.

Conclusions. A reduced mineral density of the bone tissue in schoolchildren during the growth spurt occurs due to the lack or deficit of vitamin $D_{3}$. However, the most significant factor in the MDBT reduction is the fact that the processes of the bone mass accumulation cannot keep pace with an intensive linear growth of the skeleton.

Key words: densitometry; growth spurt; vitamin D; osteoporosis.

ВСтУП. Процеси структурно-фрункціонального фрормування кісткової тканини (КТ) найбільш інтенсивно відбуваються у дитячому та підлітковому віці, коли накопичується більш ніж 90 \% генетично детермінованої кісткової тканини. По закінченню періоду статевого дозрівання і до 25-30 років фрормується пік кісткової маси, тобто максимальне накопичення мінеральних речовин та формування кісткового матриксу [1-3].

Порушення процесів кісткового моделювання в період дитинства є підвищеним ризиком суттєвої втрати кісткової маси у людини в зрілому віці, що за рахунок виникнення остеопоротичних переломів може негативно впливати не тільки на якість життя, але й призводити до інвалідизації [4-6].

Особливого значення це набуває у період другого ростового (пубертатного) спурту - істинного ростового стрибка, який характеризується інтенсивним зростанням тіла дитини в довжину в період статевого дозрівання та має вплив майже на всі системи організму [7]. Саме в цей період висока активність біологічних процесів на тлі прискореного лінійного росту може викликати прискорене моделювання КТ і супроводжуватися зниженням мінеральної щільності кісткової тканини (МЩКТ) у підлітків [8]

Добре відома важлива роль вітаміну $\mathrm{D}_{3}$ в процесах структурно-фрункціонального фрормування КТ, при недостатньому рівні якого відбувається зниження засвоєння кальцію і порушення процесів синтезу кісткового матриксу в дітей [9]. Доведено також його вплив на фрункціонування ендокринної, серцево-судинної, нервової, імунної та інших систем організму людини [10]. Проте слід зазначити, що натепер спостерігається недостатність або десріцит вітаміну D серед населення майже всіх країн світу: серед населення Європи - від 30 до 100 \%; в Україні лише 1,4 \% дитячого населення віком 10-17 років мають показники 25-(OH)- $\mathrm{D}_{3}$ в межах норми, а 92 \% школярів мають його десріцит [11].

Усе вищезазначене зумовлює важливість посиленого нагляду за дітьми, які мають ризик розвитку порушень формування КТ, особливо в період ростового спурту. Саме своєчасне обстеження дитини в цей важливий період надає можливість лікарю-педіатру і/або лікарю загальної практики - сімейної медицини визначитися 3 необхідними складовими нагляду за пацієнтом, а в раз необхідності - провести корекцію метаболічних порушень, що є запорукою забезпечення оптимальних умов фрормування КТ та просрілактики розвитку остеопорозу в майбутньому $[12,13]$.
Оцінка стану КТ проводиться на підставі клінічних та анамнестичних даних - об'єктивного огляду, частоти зламів та їхньої відповідності тяжкості травми; даних лабораторних досліджень, що відображають процеси метаболізму КТ; інструментальних досліджень, які надають лікарю інформацію про МщКТ, її архітектоніку тощо $[12,14]$. Для вимірювання МЩКТ використовують: ультразвукову денситометрію (УД), двохенергетичну рентгенівську абсорбціометрію (DXA) [2], кількісну комп'ютерну томографрію (ККТ) [15], периферичну ККТ та магнітно-резонансну томографрію (МРТ) [12]. Кожен з цих методів має як свої переваги, так і недоліки. Безумовною перевагою УД, яка базується на здатності губчастої кістки проводити ультразвук, є відсутність променевого навантаження, відносна простота проведення дослідження та швидкість отримання результатів, мобільність, можливість використовувати її для скринінгового обстеження великої кількості дітей поза межами лікарні. Проте цей метод має певні недоліки, а саме чутливість до умов проведення дослідження: вологість шкіри та кут накладення датчика, різні значення МщкТ у різних ділянках скелета та неможливість вимірювання МщКТ поперекових хребців, оскільки вимірювання проводяться на променевій або п'ятковій кістках $[4,14,16]$. «Золотим стандартом» діагностики остеопорозу та остеопенії $€$ DXA- метод, який має високу точність завдяки використанню двох енергій рентгенівських променів, які виключають вплив м'яких тканин на остаточний результат; вимірювання проводиться на поперекових хребцях та шийці стегнової кістки, що $€$ найбільш інорормативним в діагностиці зниження МЩКТ [17-19]. У той же час, слід враховувати, що даний метод передбачає використання рентгенівських променів і для його проведення потрібні чіткі показання [14, 20, 21].

Ураховуючи все вищезазначене, проведення дослідження особливостей стану КТ та їх взаємозв'язок із рівнем вітаміну D у дітей в період другого ростового спурту є актуальним і своєчасним.

МЕТА ДОсЛІДЖЕНня - визначення структурнофрункціонального стану кісткової тканини та статусу вітаміну $D_{3}$ у школярів в період другого ростового спурту.

МАТЕРІАЛИ ТА МЕТОДИ. У дослідженні брали участь 205 умовно здорових школярів віком 9-17 років: 112 хлопчиків та 93 дівчинки. Критеріями включення дітей у дослідження були: народження в строк, відповідність віку фрізичному та нервово-психічному розвитку, необтяжений сімейний анамнез (щодо захворювань кісткової, 
ендокринної систем, порушень обміну речовин тощо); діти не отримували вітамінно-мінеральних комплексів, у тому числі вітамін $\mathrm{D}_{3}$ протягом 6 місяців до обстеження. До критеріїв виключення відносили: наявність хронічної соматичної патології та хромосомної патології; відмову батьків щодо участі дитини в дослідженні.

3 урахуванням наявності ростового спурту та його інтенсивності діти були розподілені на три групи: І група - 50 дітей, які за поточний рік прибавили у рості від 8 до 12 см; II група - 46 дітей, які за поточний рік прибавили у рості більше 12 см, III група - 109 дітей, які не мали ростового спурту. Обстеження включало аналіз даних анамнезу, оцінку рівня фрізичного розвитку за перцентильними таблицями (WHO «Child Growth Standards», 2007), визначення індексу маси тіла, оцінку статевого розвитку за шкалою Таннера. 3 метою оцінки структурно-фрункціонального стану КТ використовували ультразвукову денситометрію та двохенергетичну рентгенівську абсорбціометрію. Так, УД на п'ятковій кістці використовували як скринінговий метод (апарат Sonost-2000, Корея), який проводили усім дітям, які брали участь у дослідженні; методом DXA (хребці L1 - L4, апарат HOLOGIC QDR W Explorer, USA) було обстежено 32 дитини, які мали зниження МщКТ за даними УД. Критеріями зниження мінеральної щільності КТ вважали показник Z-score $\leq-2$ (The International Society For Clinical Densitometry, 2013).

Визначення рівня 25-(OH)-D у крові проведено методом імуноферментного аналізу. Референтні показники визначали відповідно до методичних рекомендацій з лікування та профрілактики десріциту вітаміну D у населення країн Центральної Європи: рекомендовані дози препаратів вітаміну D для здорової популяції та груп ризику (2013 р.). Рівень 25-(OH)-D менше 50 нмоль/л розцінювали як десріцит вітаміну $D_{3}$, рівень 50-75 нмоль/л - як недостатність вітаміну $D_{3}$, рівень 25-(OH)- $D_{3}$ 75-125 нмоль/л вважали за оптимальний.

Для обробки отриманих результатів використовували програми Microsoft Office Excel 2007 та STATISTICA 7, проведено кореляційний аналіз за методикою Спірмена.

Дослідження було виконано згідно з принципами Гельсінської декларації прав людини, Європейської конвенції з захисту прав та гідності людини в аспекті біомедицини та згідно з законами України з мінімальними психологічними втратами з боку пацієнтів з урахуванням міжнародних біоетичних стандартів щодо згоди батьків на участь дітей у дослідженні.

РЕЗУЛЬТАТИ ДОСЛІДЖЕННЯ ТА ЇХ ОБГОВОРЕННЯ. Під час оцінки рівня фрізичного розвитку встановлено, що 26 дітей (12,7 \%) з усіх обстежених мають ризик розвитку надмірної маси, 8 дітей (3,9 \%) - надмірну масу. Статевий розвиток дітей усіх груп відповідав віковим нормам. Прояви недиференційованої дисплазії сполучної тканини (сколіотична осанка, плоскостопість, пролапс мітрального клапана, аномальна хорда лівого шлуночка тощо) мали 133 дитини (64,8 \%), з них 32 дитини (64,0 \%) І групи, 30 дітей (65,2 \%) II та 71 дитина (65,1 \%) III групи; тобто, вірогідної різниці по групах не спостерігали.

Результати УД показали, що зниження МщкТ мали 24 (48,0 \%) дитини I групи, 28 (60,87 \%) дітей II групи та 43 (39,45 \%) дитини III групи. Таким чином, діти 3 інтенсивним лінійним ростом мали достовірно вищий відсоток випадків зниження МЩКТ на відміну від дітей, які не мали ростового спурту $(p<0,05)$. Найбільший відсоток випадків зниження МщкТ спостерігали в групі дітей, які за поточний рік виросли більш ніж на 12 см. Середній

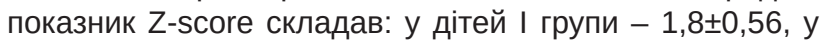

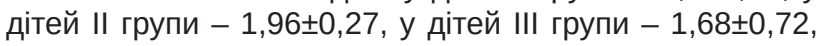
тобто найменший показник МщКТ спостерігали у дітей 3 інтенсивним ростовим спуртом $(p<0,05)$.

За допомогою DXA було обстежено 32 дитини, в яких при проведенні УД було виявлено зниження МщкТ (Z-score s-2). Результати дослідження показали, що 18 $(56,25 \%)$ дітей мають зниження МщКТ: 38,9 \% дітей із помірними показниками ростового спурту (I група) та 50,0 \% дітей з інтенсивним ростовим спуртом (II група). Слід зазначити, що як при використанні ультразвукового, так і рентгенівського методів обстеження відсоток зниження МщКТ серед дітей з інтенсивним ростовим спуртом був достовірно вищим ( $p<0,05)$, ніж у групі дітей, які не мали ростового спурту.

Результати визначення рівня вітаміну 25-(OH)-D показали наявність недостатності або дефріциту вітаміну $\mathrm{D}_{3}$ у дітей всіх груп, тобто, незалежно від інтенсивності зростання у пубертатному віці.

Так, у дітей I групи недостатність вітаміну $\mathrm{D}_{3}$ виявлено у 9 (18,0 \%), тоді як його дефіцит мала 41 дитина (82,0 \%). Середній рівень вітаміну $D_{3}$ в дітей I групи складав $(40,80 \pm 9,44)$ нмоль/л. У дітей II групи недостатність вітаміну $D_{3}$ діагностовано у $6(13,04 \%)$ випадках, а його десіцит - у 40 (86,96 \%) дітей. Середній рівень вітаміну $\mathrm{D}_{3}$ в цій групі склав $(45,6 \pm 5,14)$ нмоль/л. У дітей III групи недостатність 25-(OH)-D виявлено у 18 (16,5 \%) дітей, тоді як його десріцит - у 91 дитини (83,5 \%), а середній рівень вітаміну $D_{3}$ по групі склав $(40,47 \pm 9,49)$ нмоль/л.

Водночас, слід зазначити, що дефіцит $\mathrm{D}_{3}$ спостерігався частіше у дітей, які мали інтенсивний ростовий спурт, ніж у дітей інших груп. Привертає увагу те, що розподіл показників рівня 25-(OH)- $\mathrm{D}_{3}$ по групах (рис. 1) був неоднорідним: саме у дітей другої групи крива розподілу його значень має зсув праворуч, не досягаючи нормальних величин.

Аналіз показників середнього рівня вітаміну 25-(OH)- $\mathrm{D}_{3}$ показав, що у дітей I групи, які мали зниження МщкТ, середній рівень вітаміну $\mathrm{D}_{3}$ складав $(39,04 \pm 11,84)$ нмоль/л, тоді як у дітей з нормальною МЩКТ - $(42,43 \pm 6,3)$ нмоль/л. У дітей II групи, які мали зниження МщКТ середній рівень $25-(\mathrm{OH})-\mathrm{D}_{3}$ складав $(45,68 \pm 5,48)$ нмоль/л, а при нормальних показниках МЩКТ - $(45,47 \pm 4,69)$ нмоль/л. Однак як у I, так і у II групах достовірної різниці між показниками рівня вітаміну $\mathrm{D}_{3}$ у дітей зі зниженою та нормальною МЩКТ не відмічали. При визначенні рівня вітаміну $\mathrm{D}_{3} \mathrm{y}$ дітей III групи, які мали зниження МщКТ, його середній рівень складав $(36,73 \pm$ $8,94)$ нмоль/л, що вірогідно відрізняється від його значень у дітей з нормальною МщКТ - $(42,91 \pm 9,1)$ нмоль/л $(p<0,05)$. Це підтверджується також виявленим позитивним зв'язком $(\mathrm{r}=0,4)$ між рівнем $25(\mathrm{OH}) \mathrm{D}_{3}$ та МщКТ у дітей III групи, на відміну від аналогічних показників дітей I та II груп.

ВИСНОВКИ. 1. У дітей шкільного віку в період істинного ростового спурту має місце зниження мінеральної щільності кісткової тканини, яке відбувається на тлі недостатності або десріциту вітаміну $\mathrm{D}_{3}$.

2. У період істинного ростового спурту найбільш суттєвим чинником зниження мінеральної щільності кісткової тканини у дітей є саме особливості фрормування та нако- 
Група I

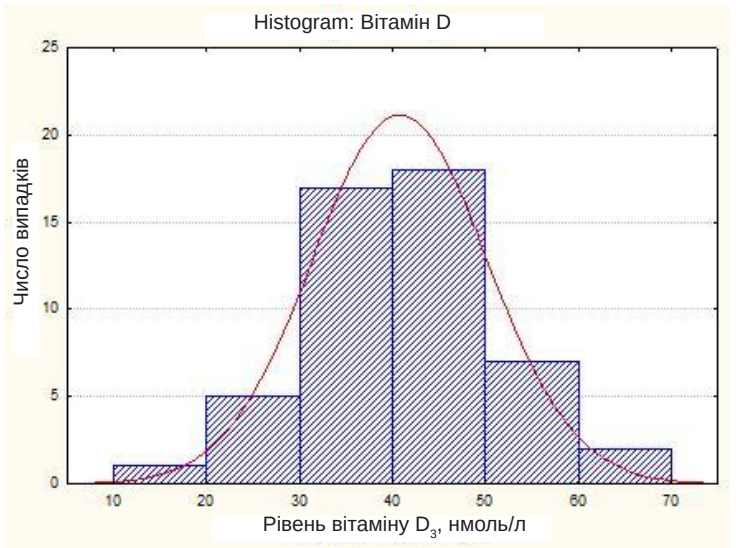

Група III

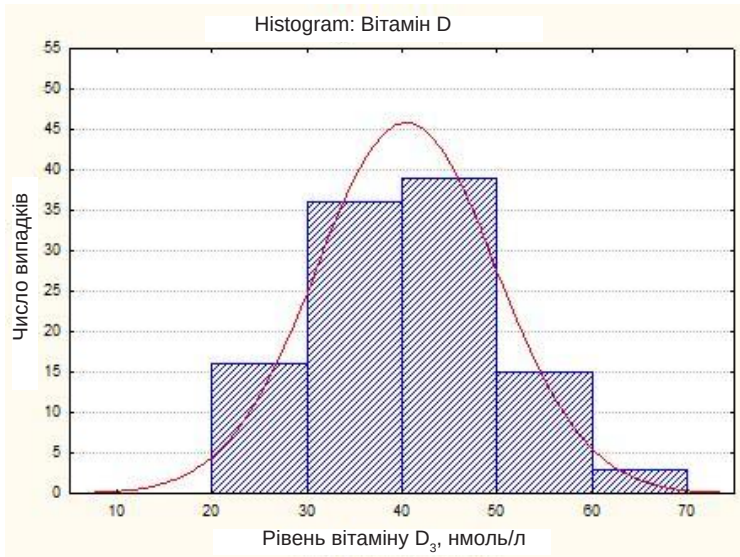

пичення кісткової маси на тлі інтенсивного лінійного росту скелета, тоді як у дітей, які не мають ростового спурту, найбільш вагомим фрактором, що сприяє фрормуванню кісткової тканини, $€$ рівень вітаміну $\mathrm{D}_{3}$

ПЕРСПЕКТИВИ ПОДАЛЬШИХ ДОСЛІДЖЕНЬ Отримані дані є підставою для подальшого вивчення біо-

\section{СПИСОК ЛІТЕРАТУРИ}

1. Ізумець О. І. Заходи з виявлення остеопенії у дітей та підлітків / О. І. Ізумець, Л. І. Лайко, Ф. Ф. Ройзман // Актуальні питання педіатрії. - 2016. - № 5 (77). - С. 30-32.

2. Жулкевич І. В. Дослідження структурно-фрункціонального стану кісткової тканини методом двосротонної рентгенівської абсорбціометрії / І. В. Жулкевич, О. Л. Ковальчук // Шпитальна хірургія. - 1999. - № 2. - С. 124-129.

3. The interrelationship of bone and cardiovascular remodeling biomarkers and clinical peculiarities of coronary artery disease in postmenopausal women / N. S. Mykhailovska, I. O. Stetsiuk, T. O. Kulynych [et al.] // Reumatologia. - 2020. - Vol. 58 (3). - P. 142-149. DOI: 10.5114/reum.2020.96687.

4. Марушко Ю. В. Ультразвукова денситометрія (аксіальне вимірювання) у діагностиці остеопенічного синдрому у дітей з різною соматичною патологією / Ю. В. Марушко, Т. І. Волоха, А. О. Аксонов // Современная педиатрия. -2016. - № 1 (73). - С. 54-58.

5. Сміян С. І. Показники мінеральної щільності кісткової тканини здорових чоловіків за результатами двофотонної рентгенівської денситометрії / С.І.Сміян, О. М. Масик, І. В. Жулкевич // Проблеми остеології. - 2002. - Т. 2. - С. 9.
Група II

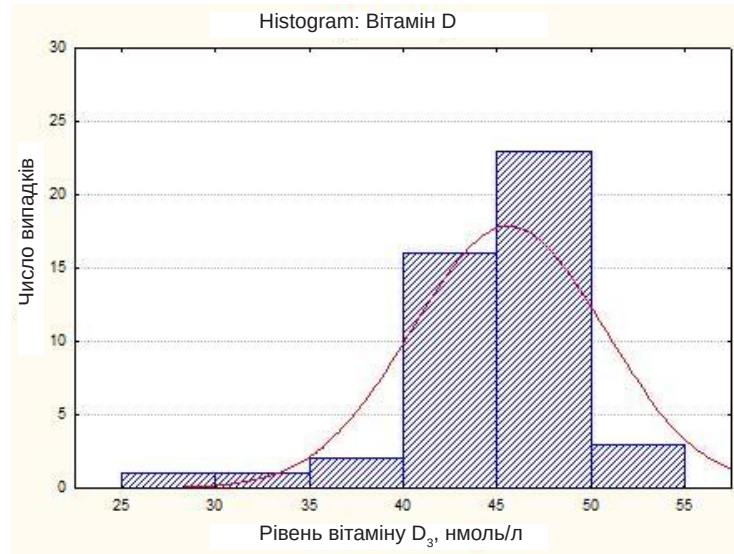

Рис 1. Розподіл рівня вітаміну $D_{3}$ по групах.

хімічних показників, що віддзеркалюють стан кісткового метаболізму, та їх взаємозв'язку із денситометричними показниками у дітей з інтенсивним ростовим спуртом 3 метою розробки прогностичних маркерів ризику розвитку порушень КТ та профрілактичних заходів щодо їх попередження.

6. Зміни мінеральної щільності кісткової тканини поперекового відділу хребта, поширення хребцевих деформацій та ризик їх виникнення при ураженні гемопоетичної системи (огляд літератури і власні дослідження) / І.В.Жулкевич, С. І. Сміян, М. Є. Гаврилюк, Л. Ю. Орищин // Вісник наукових досліджень. - 2000. - № 2. - С. 15-19.

7. Ohta H. Growth spurts of the bone from infancy to puberty / H. Ohta // Clin. Calcium. - 2019. - Vol. 29 (1). - P. 9-17.

8. Минеральная плотность кости у детей в разные возрастные периоды / С. В. Мальцев, Г. Ш. Мансурова, Т. В. Колесниченко, Н. А. Зотов // Практическая медицина. - 2013. - № 6 (75). - C. 106-108.

9. Маковкіна Ю. А. Метаболізм кісткової тканини в дитячому віці та його діагностика / Ю. А. Маковкіна // Перинатология и педиатрия. Актуальные вопросы педиатрии. - 2014. № 2 (58). - С. 37-40.

10. Майданник В. Г. Современные подходы к профилактике и лечению витамин-Д дефицитного рахита с позиции доказательной медицины / В. Г. Майданник, С. М. Демчук // Міжнар. журн. педіатр., акуш. та гінекол. - 2015. - Вип. 8, № 1. - C. 133-143. 
11. Українська асоціація остеопорозу. [Електронний ресурс]. - Режим доступу: http://osteoporos.com.ua/deficitvitamina-d.

12. Update on bone density measurements and their interpretation in children and adolescents / N. Dilorgi, K. Maruca, G. Patti, S. Mora // Best. Pract. Res. Clin. Endocrinol. Metab. 2018. - No. 32 (4). - P. 477-498.

13. Масик О. М. Сучасні аспекти застосування біфосфронатів у клінічній практиці (огляд літератури) / О. М. Масик С. І. Сміян, І. В. Жулкевич // Журнал АМН України. - 2000. T. 6, № 4. - С. 713-721.

14. Бахшиев Б. А. Оценка метода денситометрии тазобедренного сустава и пяточной кости / Б. А. Бахшиев, Ш. Р. Мамедова // Здоровье женщины. - 2016. - № 2 (108). - С. 112-114.

15. Жулкевич І. В. Клініко-діагностична апробація методу віртуальної біопсії кісткової тканини у хворих на ліморому Годжкіна / І. В. Жулкевич, Ю. В. Яворська // Український радіологічний журнал. - 2015. - Т. XXIII. - С. 31-34.

\section{REFERENCES}

1. Izumets, O.I., Layko, L.I., \& Royzman, F.F. (2016). Zakhody z vyiavlennia osteopenii u ditei ta pidlitkiv [Measures to detect osteopenia in children and adolescents]. Aktualni pytannia pediatrii - Current Issues of Pediatrics, 5 (77), 30-32 [in Ukrainian].

2. Zhulkevych, I.V., \& Kovalchuk, O.L. (1999). Doslidzhennia strukturno-funktsionalnoho stanu kistkovoi tkanyny metodom dvofotonnoi renthenivskoi absorbtsiometrii [Investigation of the structural and functional state of bone tissue by two-photon $\mathrm{X}$ ray absorptiometry]. Shpytalna khirurhiia - Hospital Surgery, 2, 124-129 [in Ukrainian].

3. Mykhailovska, N.S., Stetsiuk, I.O., Kulynych, T.O., Gorbachova, S.V., \& Zhulkevych, I.V. (2020). The interrelationship of bone and cardiovascular remodeling biomarkers and clinical peculiarities of coronary artery disease in postmenopausal women. Reumatologia, 58 (3), 142-149. DOI: 10.5114/ reum.2020.96687.

4. Marushko, Yu.V., Volokha, T.I., \&Aksonov, A.O. (2016). UItrazvukova densytometriia (aksialne vymiriuvannia) u diahnostytsi osteopenychnoho syndromu u ditey z riznoiu somatychnoiu patolohiieiu [Ultrasonic densitometry (axial measurement) in the diagnosis of osteopenic syndrome in children with various somatic pathologies]. Sovremennaya pedyatryya - Modern Pediatrics, 1 (73), 54-58 [in Ukrainian].

5. Smiyan, S.I., Masyk, O.M., \& Zhulkevych, I.V. (2002). Pokaznyky mineralnoi shchilnosti kistkovoi tkanyny zdorovykh cholovikiv za rezultatamy dvofotonnoi renthenivskoi densytometrii [Indicators of bone mineral density of healthy men on the results of dual energy $X$-ray densitometry]. Problemy osteolohii - Problems of Osteology, 2, 9 [in Ukrainian].

6. Zhulkevych, I.V., Smiyan, S.I., Havrylyuk, M.Ye., \& Oryshchyn, L.Yu. (2000). Zminy mineralnoi shchilnosti kistkovoi tkanyny poperekovoho viddilu khrebta, poshyrennia khrebtsevykh deformatsii ta ryzyk yikh vynyknennia pry urazhenni hemopoetychnoi systemy (ohliad literatury i vlasni doslidzhennia) [Changes in the mineral density of bone tissue of the lumbar spine, the spread of vertebral deformities and the risk of their occurrence in the defeat of the hematopoietic system (literature review and own research)]. Visnyk naukovykh doslidzhen Bulletin of Scientific Research, 2, 15-19 [in Ukrainian].

7. Ohta, H. (2019). Growth spurts of the bone from infancy to puberty. Clin. Calcium, 29 (1), 9-17.
16. Калиниченко Ю. А. Оценка фракторов риска снижения минеральной плотности костной ткани у подростков с зубочелюстными аномалиями / Ю. А. Калиниченко, Т. А. Сиротченко // Бюллетень сибирской медицины. - 2016. - № 15 (4). - C. 52-58.

17. The International Society for Clinical Densitometry (ISCD). - URL : https://www.iscd.org.

18. Українська асоціація остеопорозу. [Електронний ресурс]. - Режим доступу: http://osteoporos.com.ua/ukrainskaasociacija-osteoporozu.

19. Жулкевич І. В. Методика дослідження щільності кісткової тканини проксимального відділу стегна подвійною рентгенівською абсорбціометрією / І. В. Жулкевич // Вісник наукових досліджень. - 1999. - № 3. - С. 37-39.

20. Berry M. E. Using DXA to identify and treat osteoporosis in pediatric patients / M. E. Berry // Radiol. Technol. - 2018. № 89 (3). - Р. 312-317.

21. Сміян С. І. Нові підходи до оцінки структурно-функціональних характеристик кісткової тканини за даними лонгітудинальної кісткової денситометрії / С. І. Сміян, І.В.Жулкевич, О. М. Масик // Шпитальна хірургія. -2000. - № 1. - С. 134-136.

8. Maltsev, S.V., Mansurova, G.SH., Kolesnichenko, T.V., \& Zotov, N.A. (2013). Mineralnaya plotnost kosti u detey v raznyye vozrastnyye periody [Bone mineral density in children in different age periods]. Prakticheskaya meditsina - Practical Medicine, 6 (75), 106-108 [in Russian].

9. Makovkina, Yu.A. (2014). Metabolizm kistkovoi tkanyny v dytiachomu vitsi ta yoho diahnostyka [Metabolism of bone tissue in childhood and its diagnosis]. Perinatologiya i pediatriya. Aktualnye voprosy pediatrii - Perinatology and Pediatrics. Current issues of pediatrics, 2 (58), 37-40 [in Ukrainian].

10. Maydannik, V.G., \& Demchuk, S.M. (2015). Sovremennyye podkhody k profilaktike i lecheniyu vitamin-D defitsitnogo rakhita s pozitsii dokazatelnoy meditsiny [Modern approaches to the prevention and treatment of vitamin-D deficient rickets from the standpoint of evidence-based medicine]. Mizhnar. zhurn. pediatr., akush. ta hinekol. - Int. J. Pediatr., Obstet. Gynecol., 8, 1, 133-143 [in Ukrainian].

11. Ukrainska asotsiatsiia osteoporozu [Ukrainian Osteoporosis Association]. Retrieved from: http://osteoporos.com. ua/deficit-vitamina-d.

12. Dilorgi, N., Maruca, K., Patti, G., \& Mora, S. (2018). Update on bone density measurements and their interpretation in children and adolescents. Best. Pract. Res. Clin. Endocrinol. Metab., 32 (4), 477-498.

13. Masyk, O.M., Smiyan, S.I., \& Zhulkevych, I.V. (2000). Suchasni aspekty zastosuvannia bifosfonativ u klinichnii praktytsi (ohliad literatury) [Modern aspects of the use of bisphosphonates in clinical practice (literature review)]. Zhurnal AMN Ukrainy - J. Acad. Med. Sci. Ukraine., 6, 4, 713-721 [in Ukrainian].

14. Bakhshiyev, B.A., \& Mamedova, Sh.R. (2016). Otsenka metoda densitometrii tazobedrennogo sustava i pyatochnoy kosti [Evaluation of the method of densitometry of the hip joint and calcaneus]. Zdorovye zhenshchiny - Women's Health, 2 (108), 112-114 [in Russian].

15. Zhulkevych, I.V., \& Yavorska, Yu.V. (2015). Klinikodiahnostychna aprobatsiia metodu virtualnoi biopsii kistkovoi tkanyny u khvorykh na limfomu Hodzhkina [Clinical and diagnostic testing of the method of virtual biopsy of bone tissue in patients with Hodgkin's lymphoma]. Ukrainskyi radiolohichnyi zhurnal - Ukrainian Journal of Radiology, XKHIII, 31-34 [in Ukrainian].

16. Kalinichenko, Yu.A., \& Sirotchenko, T.A. (2016). Otsenka faktorov riska snizheniya mineralnoy plotnosti kostnoy tkani u 
podrostkov s zubochelyustnymi anomaliyami [Evaluation of risk factors for a decrease in bone mineral density in adolescents with dentoalveolar anomalies]. Byulleten sibirskoy meditsiny Bulletin of Siberian Medicine, 15 (4), 52-58 [in Russian].

17. The International Society for Clinical Densitometry (ISCD). Retrieved from: https://www.iscd.org.

18. Ukrainska asotsiatsiia osteoporozu [Ukrainian Osteoporosis Association]. Retrieved from: http://osteoporos.com.ua/ ukrainska-asociacija-osteoporozu.

19. Zhulkevych, I.V. (1999). Metodyka doslidzhennia shchilnosti kistkovoi tkanyny proksymalnoho viddilu stehna podviinoiu renthenivskoiu absorbtsiometriieiu [Methods of research of bone density of proximal femur by double X-ray absorptiometry]. Visnyk naukovykh doslidzhen - Bulletin of Scientific Research, 3, 37-39 [in Ukrainian].

20. Berry, M.E. (2018). Using DXA to identify and treat osteoporosis in pediatric patients. Radiol. Technol., 89 (3), 312-317.

21. Smiyan, S.I., Zhulkevych, I.V., \& Masyk, O.M. (2000). Novi pidkhody do otsinky strukturno-funktsionalnykh kharakterystyk kistkovoi tkanyny za danymy lonhitudynalnoi kistkovoi densytometrii [New approaches to the assessment of structural and functional characteristics of bone tissue according to the data of longitudinal bone densitometry]. Shpytalna khirurhiia Hospital Surgery, 1, 134-136 [in Ukrainian].

Отримано 28.05.20

Прийнято до друку 22.06.20

Електронна адреса для листування: natasha-osman@ukr.net 